\title{
The formation of the leaf surface area and biomass of the miscanthus giganteus plants depending on the sewage sludge rate
} \author{
Jakubowski 6 \\ ${ }^{1}$ National University of Life and Environmental Sciences, Kyiv, 03041, Ukraine \\ ${ }^{2}$ Ivano-Frankivsk National Technical University of Oil and Gas, Ivano-Frankivsk, 76019, Ukraine \\ ${ }^{3}$ Institute of Energy Crops and Sugar Beet, Kiyv, 03141, Ukraine \\ ${ }^{4}$ Dnipro State Agrarian and Economic University, Dnipro, 49600, Ukraine \\ ${ }^{5}$ University of Technology and Life Sciences in Bydgoszcz, Bydgoszcz, 85-796, Poland \\ ${ }^{6}$ University of Agriculture in Krakow, Krakow, 31-120, Poland
}

Vasyl Lopushniak ${ }^{1}$, Halyna Hrytsuliak ${ }^{2}$, Mykhailo Gumentyk ${ }^{3}$, Mykola Kharytonov $^{4, *}$, Bazena Barchak $^{5}$, and Tomasz

\begin{abstract}
The case study to determine the peculiarities of Miscanthus giganteus aboveground biomass formation depending on sewage sludge and composts rate carried out in the Precarpathian region of IvanoFrankivsk province on sod-podzolic soils. The largest area of the leaf surface of miscanthus is formed in the trials where fresh sewage sludge was applied in the rate of $20-40 \mathrm{t} / \mathrm{ha}$. The leaf surface area increases from 19 up to $24.0 \mathrm{~cm} 2 /$ plant, and the yield of raw mass of plants at the level of $23.5-25.1 \mathrm{t} / \mathrm{ha}$ due to increasing rates of sewage sludge application. The highest indicators of net photosynthesis productivity were found in the period of intensive growth, which amounted to $7.78 \mathrm{~g} / \mathrm{m}^{2} /$ day and in the maturation period of 7.56 $\mathrm{g} / \mathrm{m}^{2} /$ day in the trial SS $-40 \mathrm{t} / \mathrm{ha}+\mathrm{N}_{10} \mathrm{P}_{14} \mathrm{~K}_{58}$. The amount of dry mass of miscanthus plants significantly depends on the height of the shoot and the leaf surface area of the plants. The use of compost based on sewage sludge and straw in a ratio of $3: 1$ at a rate of $30 \mathrm{t} / \mathrm{ha}$ contributes to the dry weight of miscanthus plants at the level of $15 \mathrm{t} / \mathrm{ha}$.
\end{abstract}

\section{Introduction}

The three main land-use groups in EU are: built-up areas, forest and agricultural land including mixed croplivestock, pasture/livestock grazing, permanent crop production systems and bioenergy crops [1]. The biomass of energy crops occupies an important place in solving the problem of replacing traditional energy sources with alternative ones. Oil crops $(82 \%$ of the land used for biodiesel fuel production) took first place in EU countries in 2015 [2]. The rest area for the production of ethanol crops (11\%), biogas (7\%), and heat generation (1\%) used. Dedicated energy crops are mainly perennial grasses (miscanthus or switchgrass) and short rotation coppice such as willow or poplar. Poland, France, Germany, Spain, Romania, Sweden and the United Kingdom are the largest energy crops producer countries of the total European acreage [3-5]. For instance, withdrawn in 2009 short rotation plantations scheme was granted in Poland at national level for such energy crops as willow, poplar, Miscanthus and Sida hermaphrodita [6].

According to European experts, the area of land available for growing energy crops in 2020 will increase up to 20.5 million hectares, and in 2030 - up to 26.2 million hectares. Today 8 million hectares are unproductive in Ukraine [7]. Growing energy crops on marginal lands makes sense to estimate the use of some wastes. These wastes considered as fertilizers available to promote high yields [8]. Meantime the question about the fertilization impact on energy crops availability as biofuel is still an open debate $[9,10]$.

A wide range of feedstocks is available in abundance for biofuel production in industrialized countries using municipal solid waste [11]. The use of biomass residues, municipal and agri-waste as primary resource for biofuels is a promising proposal to reduce technogenic load connected with the waste disposal. Biomass is the biodegradable fraction of products, wastes, and residues of biological origin from agriculture (including plant and livestock), forestry, and related industries, including fisheries and aqua culture, as well as the biodegradable fraction of industrial and household waste [12]. Municipal sewage sludge considered as potential source of macroelements, which recovered during the production of energy crop biomass [13 - 16]. It is composed of a wide range of organic matter $(\mathrm{OM})$, microorganisms, macroand micro-nutrients, non- organic and organic micro pollutants [17] All these components indispensable for proper functioning of plants in optimum quantities and proportions for fertilization purposes [18]. However,

\footnotetext{
* Corresponding author: kharytonov.m.m@dsau.dp.ua
} 
sewage sludge also contains heavy metals, polycyclic aromatic hydrocarbons (PAHs) and polychlorinated biphenyls (PCBs) [19-21]. The combination of different methods and the modification of chemical immobilizing agents both improved the fixation effect on heavy metals [22]. It allowed introducing municipal sewage sludge for growing crops at arable lands a dose of not more than 10 tons/ha for three years according to the Ukrainian state standard [23]. Large doses are possible in the case of mineland reclamation after three years monitoring, calculation of heavy metals uptake with energy crops yield and forthcoming life cycle assessment availability of municipal sewage sludge and other soil amendments application [24]. Fertilization at certain stages of the energy grass lifespan can maintain plantation production performance even in the later years of cultivation [25]. Agronomic and energy efficiency analysis to evaluate the effects of sewage sludge applied at rates equivalent to 100 and $160 \mathrm{~kg} \mathrm{~N} \mathrm{ha}^{-1}$ on the production of giant miscanthus made [26]. Energy efficiency was $43-52 \%$ higher when giant miscanthus plants with sewage sludge rather than mineral fertilizers supplied. The highest energy value of biomass yield was in the treatments with $20 \mathrm{MgDMha}^{-1}$ of sludge application [27]. The knowledge about the effect of large doses of sewage sludge on the energy crops longterm plantations is insufficient [28, 29]. Perennial herbaceous plants are considered to be promising for cultivation. Miscanthus as a relatively new energy crop for Ukraine requires additional study on the efficiency of cultivation in different soil and climatic conditions [30 32]. Miscanthus $\times$ giganteus can produce a high yield of aboveground biomass at relatively low input costs $[33$, 34]. Miscanthus can improve soil structure and levels of organic matter in marginal lands [35] and use for both liquid and solid biofuels production as raw material [36]. The crop characterize by extensive root/rhizome growth. This process can reduce soil compaction and allow a greater water buffering capacity [37]. The use of sewage sludge could not only increase yield but also positively affect biological and physico - chemical properties of soil profile [38]. It is known also that the intensity of organic matter accumulation depends on the size of the leaf surface, which is determined by the biometric parameters of plants and largely depends on their nutrition requirements [39, 40]. Miscanthus leaves take great importance for the formation and intensity of biomass accumulation [41]. During the season of plant vegetation, the shape and size of the leaf surface varies considerably $[42,43]$. That is why it difficult to conduct biometric measurements. The aim of our research was to determine the dependence of the size of the leaf surface area and miscanthus biomass on different rates of sewage sludge and compost made on its basis.

\section{Materials and methods}

The field experiment was carried out during 2016 - 2019 in the sod-podzolic gley medium loamy soil at the territory of the Maidan village situated in Tysmenytsia district of Ivano-Frankivsk province. The scheme of field experiments included the following options: 1 . Without fertilizers - control; 2. $\mathrm{N}_{60} \mathrm{P}_{60} \mathrm{~K}_{60} ; 3 . \mathrm{N}_{90} \mathrm{P}_{90} \mathrm{~K}_{90} ; 4$. Sewage Sludge (SS) - $20 \mathrm{t} / \mathrm{ha}+\mathrm{N}_{50} \mathrm{P}_{52} \mathrm{~K}_{74} ; 5$. SS - $30 \mathrm{t} / \mathrm{ha}+$ $\mathrm{N}_{30} \mathrm{P}_{33} \mathrm{~K}_{66} ; 6$. SS - $40 \mathrm{t} / \mathrm{ha}+\mathrm{N}_{10} \mathrm{P}_{14} \mathrm{~K}_{58} ; 7$. Compost $20 \mathrm{t} /$ ha $+\mathrm{N}_{50} \mathrm{P}_{16} \mathrm{~K}_{67} ; 8$. Compost 30 t/ha $+\mathrm{N}_{30} \mathrm{~K}_{55}$.

The sewage sludge and straw mixed in ratio $3: 1$ to prepare compost. Leaf area was determined by scanning 20 plants in each trial. After the measurement, the sheets were cut into pieces up to $25 \mathrm{~cm}$ long. The cutted parts of one sheet were folded into a transparent envelope (stationery file) in such a way that the individual pieces did not touch each other. After that, files with parts of the sheet were scanned. The same resolution was provided for all scanned images.

The analysis of the scanned images was performed using the Area S 2.1 program [44, 45]. The net productivity of photosynthesis was determined as the accumulation of dry matter per day per unit area of leaves. Measurements were performed during the growing season and determined the average. Net photosynthesis productivity defined as the accumulation of total plant biomass (every 20 days during the growing season) relative to the average leaf area over the same period.

Crop accounting performed by the method of continuous mowing of biomass in the accounting area and weighing the green mass to determine the dry matter content 3 times. The dry matter content determined by thermostatic weight method at a temperature of $105^{\circ} \mathrm{C}$.

\section{Results}

During the four years of research, the average height of miscanthus plants in the field experiment varied from $1.85 \mathrm{~m}$ to $2.95 \mathrm{~m}$ (Table 1 ). The height of plants increased by 14 and $23 \%$ in the trials 2 and 3 respectively compared to the control. The additional height growth in three next options (4-6) was fixed in combination SS $-40 \mathrm{t} / \mathrm{ha}+\mathrm{N}_{10}$ $\mathrm{P}_{14} \mathrm{~K}_{58}$. During the application of compost based on sewage sludge and straw best result on height, number of plant stems and output of dry biomass was obtained in trial 8 (30 t / ha $+\mathrm{N}_{30} \mathrm{~K}_{55}$ ). The number of plant stems increased with the amount of applied fertilizers based on sewage sludge at the rate of 20 - $40 \mathrm{t} / \mathrm{ha}$ (options 4 - 6) from 6 to 13 pieces $/ \mathrm{m}^{2}$ compared to the control (option 1). Application of sewage sludge and straw compost at the rate of $20-30 \mathrm{t} / \mathrm{ha}$ (options $7-8$ ) led to the number of stems increasing up to $16-22 \mathrm{pcs} / \mathrm{m}^{2}$ higher than at the control. The dependence of the leaf surface area on the height of miscanthus plants established using the method of correlation analysis (Fig. 1). The plant height and the leaf surface area were in the control variant $1.85 \mathrm{~m}$, and $11.5 \mathrm{~cm}^{2} /$ plant correspondingly. The application of mineral fertilizers in the dose $\mathrm{N}_{60-90} \mathrm{P}_{60-90} \mathrm{~K}_{60-90}$ (options 2 and 3 ) increased the height of plants by $0.26-0.44 \mathrm{~m}$, and the leaf surface area - by $2.0-2.5 \mathrm{~cm}^{2} /$ plant. The sewage sludge at the rate of $20-40 \mathrm{t} / \mathrm{ha}$ (options $4-6$ ) impact on the plant height and leaf surface area was $2.24-2.72 \mathrm{~m}$, and $18.5-23.8 \mathrm{~cm}^{2} /$ plant respectively. 
Table 1. Miscanthus productivity parameters depending on sewage sludge rate application.

\begin{tabular}{|c|c|c|c|c|c|c|}
\hline № & Trials & $\begin{array}{l}\text { Height of the } \\
\text { main shoot, } m\end{array}$ & $\begin{array}{c}\text { Number of } \\
\text { stems, pcs } / \mathbf{m}^{2}\end{array}$ & $\begin{array}{c}\text { Dry biomass } \\
\text { yield, } t / h a\end{array}$ & $\begin{array}{l}\text { Moisture content in } \\
\text { biomass, \% }\end{array}$ & $\begin{array}{c}\text { The output of dry } \\
\text { biomass, } t / \text { ha }\end{array}$ \\
\hline 1 & Control & 1.85 & 16 & 22.1 & 21.4 & 10.0 \\
\hline 2 & $\mathrm{~N}_{60} \mathrm{P}_{60} \mathrm{~K}_{60}$ & 2.11 & 20 & 23.0 & 27.8 & 10.4 \\
\hline 3 & $\mathrm{~N}_{90} \mathrm{P}_{90} \mathrm{~K}_{90}$ & 2.29 & 25 & 23.8 & 29.2 & 11.0 \\
\hline 4 & $\begin{array}{c}\mathrm{SS}-20 \mathrm{t} / \mathrm{ha}+ \\
\mathrm{N}_{50} \mathrm{P}_{52} \mathrm{~K}_{74}\end{array}$ & 2.24 & 22 & 23.5 & 26.1 & 10.6 \\
\hline 5 & $\begin{array}{c}\text { SS -30 t/ha + } \\
\mathrm{N}_{30} \mathrm{P}_{33} \mathrm{~K}_{66} \\
\end{array}$ & 2.56 & 26 & 24.4 & 28.7 & 11.7 \\
\hline 6 & $\begin{array}{c}\mathrm{SS}-40 \mathrm{t} / \mathrm{ha}+ \\
\mathrm{N}_{10} \mathrm{P}_{14} \mathrm{~K}_{58} \\
\end{array}$ & 2.72 & 29 & 25.1 & 31.6 & 12.2 \\
\hline 7 & $\begin{array}{c}\text { SSCompost- } 20 \mathrm{t} / \mathrm{ha}+ \\
\mathrm{N}_{50} \mathrm{P}_{16} \mathrm{~K}_{67} \\
\end{array}$ & 2.81 & 32 & 26.0 & 32.4 & 12.8 \\
\hline 8 & $\begin{array}{c}\text { SSCompost- } 30 \mathrm{t} / \mathrm{ha}+ \\
\mathrm{N}_{30} \mathrm{~K}_{55} \\
\end{array}$ & 2.95 & 38 & 26.9 & 32.9 & 13.0 \\
\hline & $\mathrm{LSD}_{0.05}$ & 0.5 & 1.0 & 0.3 & 1.2 & 0.2 \\
\hline
\end{tabular}

However, the leaf surface area of miscanthus plants was $6.1-8.4 \mathrm{~cm}^{2} /$ plant more than the leaf area of plants of the control variant in case of applying compost based on sewage sludge at the rate of $20-30 \mathrm{t} /$ ha (options 7 and 8). The correlation dependence of the leaf surface area on the height of miscanthus plants described by the following multiple regression equation:

$$
y=7.1678+0,0143 x
$$

where $y$ - is the area of the leaf surface, $\mathrm{cm}^{2} /$ plant; $x-$ plant height, $\mathrm{m}$. It was determined that the leaf surface area of miscanthus plants depends on the height of the plant. This dependence can be considered as close, because the coefficient of determination is $\mathrm{R}^{2}=0.69$, and the correlation coefficient $r=0.74$.

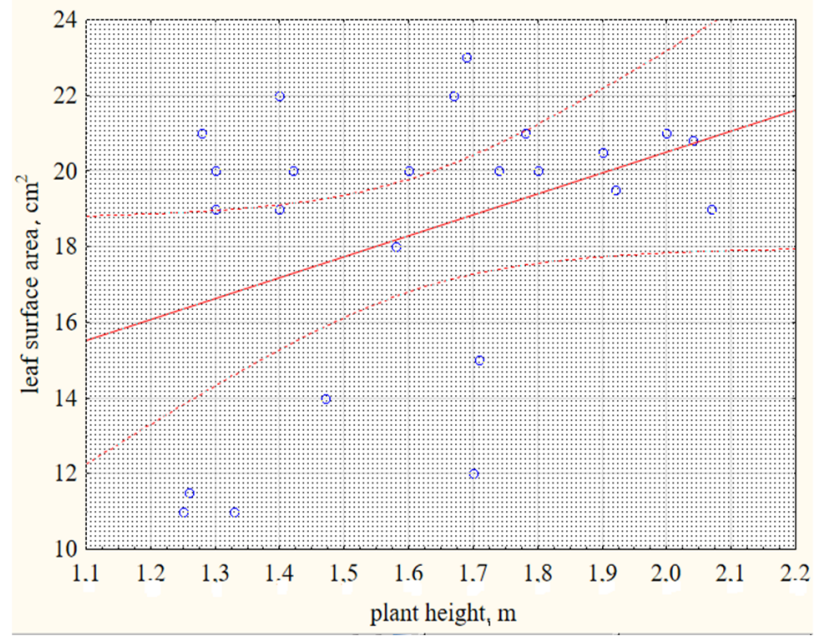

Fig. 1. Correlation dependence of leaf surface area on the height of miscanthus plants, average for 2016-2019.

The leaf surface area of miscanthus plants significantly depends on the number of stems and the height of shoots (Fig. 2).

The height of the dewlines was $2.24-2.72 \mathrm{~m}$, the area of the leafy surface was apparently $18.5-24.0$ $\mathrm{cm}^{2} /$ dewline, and the number of dewlines - $11.3-12.7$ $\mathrm{pcs} / \mathrm{m}^{2}$ for the siege of sewage waters near the rate $20-40$ t/ha (options 4 - 6).

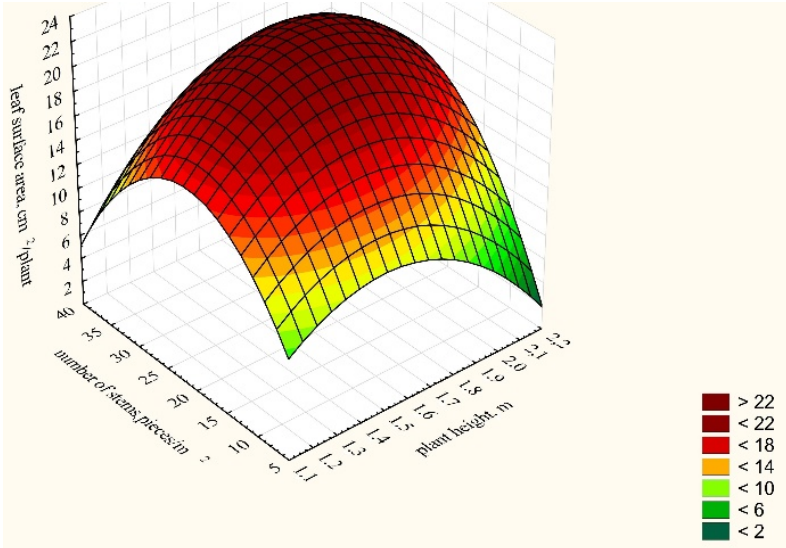

Fig. 2. Dependence of the leaf surface area on the number of stems and the height of the miscanthus shoot, average for 2016 $-2019$.

The fallowness of the area of the leafy top of the number of stalks and the height of the pagoon of the muscanthus can be described by the following simple regression:

$$
\begin{gathered}
c=1729.6509-14.683 x-75.8414 y-0.017 x^{2}+1.2845 x y \\
-2.5305 y^{2}
\end{gathered}
$$

where: $\mathrm{c}$ - the area of the leaf surface, $\mathrm{cm}^{2} /$ plant; $\mathrm{x}$ - height of the growth, $\mathrm{m} ; \mathrm{y}$ - the number of stems, $\mathrm{pcs} / \mathrm{m}^{2}$.

Miscanthus belongs to the plants of the $\mathrm{C}_{4}$ group of photosynthesis, which are able to intensively accumulate the sun energy during the vegetation period [46]. This plant is highly resistant to diseases and pests [47]. About $95 \%$ of the total plant biomass is formed in the process of photosynthesis. The dynamics of accumulation of dry plant biomass reflects the intensity of its assimilation process [48]. The power of the assimilation apparatus and the duration of its operation is a decisive factor in the productivity of photosynthesis [49]. The dynamics of the formation of the photosynthetic apparatus in miscanthus is similar to other taller plants. [50]

\footnotetext{
* Corresponding author: kharytonov.m.m@dsau.dp.ua
} 
The net productivity of photosynthesis (NPP) of miscanthus plants varies according to the surface area of the leaves (Table 2).

The introduction of $20-40 \mathrm{t} / \mathrm{ha}$ of SS and mineral fertilizers (options 4 - 6) impact on NPP at the initial growth was $3.64-3,73 \mathrm{~g} / \mathrm{m}^{2}$ per day. The NPP at the initial growth increased and amounted to $3.65-3.69 \mathrm{~g} / \mathrm{m}^{2}$ per day with the application of composts based on sewage sludge (options 7 - 8). Meantime the NPP at the initial growth was $3.65 \mathrm{~g} / \mathrm{m}^{2}$ per day with the application of mineral fertilizers at the rate of $\mathrm{N}_{90} \mathrm{P}_{90} \mathrm{~K}_{90}$ (option 3).

Table 2. Net productivity of photosynthesis of miscanthus plants depending on fertilizer application rates, $\mathrm{g} / \mathrm{m}^{2}$ per day.

\begin{tabular}{|c|c|c|c|c|}
\hline No & Trials & $\begin{array}{c}\text { Initial } \\
\text { growth }\end{array}$ & $\begin{array}{c}\text { Intensive } \\
\text { growth }\end{array}$ & Maturation \\
\hline 1 & Control & 3.55 & 7.45 & 7.30 \\
\hline 2 & $\mathrm{~N}_{60} \mathrm{P}_{60} \mathrm{~K}_{60}$ & 3.61 & 7.58 & 7.39 \\
\hline 3 & $\mathrm{~N}_{90} \mathrm{P}_{90} \mathrm{~K}_{90}$ & 3.65 & 7.63 & 7.45 \\
\hline 4 & SS $20 \mathrm{t} / \mathrm{ha}+\mathrm{N}_{50} \mathrm{P}_{52} \mathrm{~K}_{74}$ & 3.64 & 7.61 & 7.40 \\
\hline 5 & $\mathrm{SS} 30 \mathrm{t} / \mathrm{ha}+\mathrm{N}_{30} \mathrm{P}_{33} \mathrm{~K}_{66}$ & 3.68 & 7.69 & 7.47 \\
\hline 6 & $\mathrm{SS} 40 \mathrm{t} / \mathrm{ha}+\mathrm{N}_{10} \mathrm{P}_{14} \mathrm{~K}_{58}$ & 3.73 & 7.78 & 7.56 \\
\hline 7 & $\begin{array}{l}\begin{array}{l}\text { Compost } 20 \mathrm{t} / \mathrm{ha}+ \\
{ }_{0} \mathrm{P}_{16} \mathrm{~K}_{67}\end{array} \\
\end{array}$ & 3.65 & 7.60 & 7.38 \\
\hline \multirow[t]{2}{*}{8} & Compost $30 \mathrm{t} / \mathrm{ha}+\mathrm{N}_{30} \mathrm{~K}_{55}$ & 3.69 & 7.65 & 7.44 \\
\hline & $\operatorname{LSD}_{0.05}$ & 0.01 & 0.03 & 0.01 \\
\hline
\end{tabular}

The NPP at the intensive growth of plants was the highest during the introduction of sewage sludge and was7.61 - $7.78 \mathrm{~g} / \mathrm{m}^{2}$ per day (options $4-6$ ), which is 0.11 - $0.33 \mathrm{~g} / \mathrm{m}^{2}$ per day more than in control (option 1 ). The NPP at the intensive growth decreased by $0.1-0.4 \mathrm{~g} / \mathrm{m}^{2}$ per day with the application of composts (options 7 - 8) compared to the sewage sludge options $4-6$ data.

The NPP during maturation remained the highest with the introduction of sewage sludge at the rate of $40 \mathrm{t} / \mathrm{ha}+$ $\mathrm{N}_{10} \mathrm{P}_{14} \mathrm{~K}_{58}$ and amounted to $7.56 \mathrm{~g} / \mathrm{m}^{2}$ per day. According to the obtained research results, the photosynthetic activity of plants in different vegetation periods remained the largest in the variants where sewage sludge was applied.

The net productivity of photosynthesis depended on the leaf surface area of miscanthus plants (Fig. 3).

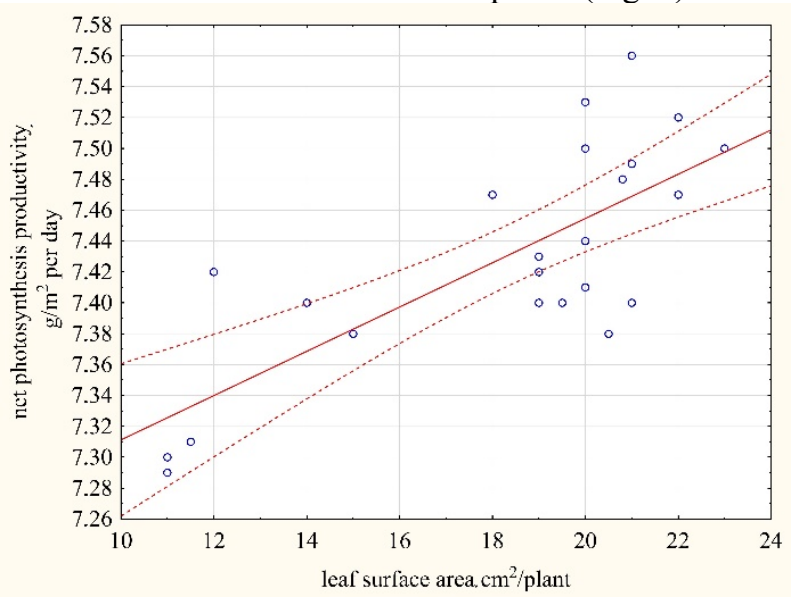

Fig. 3. Dependence of net productivity of photosynthesis on the leaf surface area of miscanthus plants, average for 2016 - 2019.
The net productivity of photosynthesis of miscanthus plants significantly depends on leaf surface area of miscanthus plants. The dependence of the net productivity of photosynthesis on the leaf surface area of the miscanthus plant described by the following regression equation:

$$
y=6.821+0.0556 x
$$

where: $y$ is the area of the leaf surface, $\mathrm{cm}^{2} /$ plant; $x$ - net productivity of photosynthesis, $\mathrm{g} / \mathrm{m}^{2}$ per day. The coefficient of determination $\mathrm{R}^{2}$ was 0.79 , i.e. the closeness of the connection can be considered as significant. There is a positive relationship between the net productivity of photosynthesis of miscanthus plants with the leaf surface area and the rate of fertilizer application. The dry mass yield of miscanthus plants depends on the height of the shoot and the area of the leaf surface of the plants (Fig. 4).

The dependence of the amount of dry mass of miscanthus plants on the height of the shoot and the area of the leaf surface can be described by the following equation:

$$
\begin{gathered}
c=12.1185-0.1587 x+2.3991 y-0.00766 x^{2}+0.3554 x y- \\
0.71084 y^{2}
\end{gathered}
$$

where: $\mathrm{c}$ is the yield of dry mass of the plant, $\mathrm{t} / \mathrm{ha} ; x$ is the area of the leaf surface, $\mathrm{cm}^{2} /$ plant; $y$ - plant height, $\mathrm{cm}$. The multiple coefficient of determination $\left(\mathrm{R}^{2}=0.74\right)$ indicates a close correlation between these indicators.

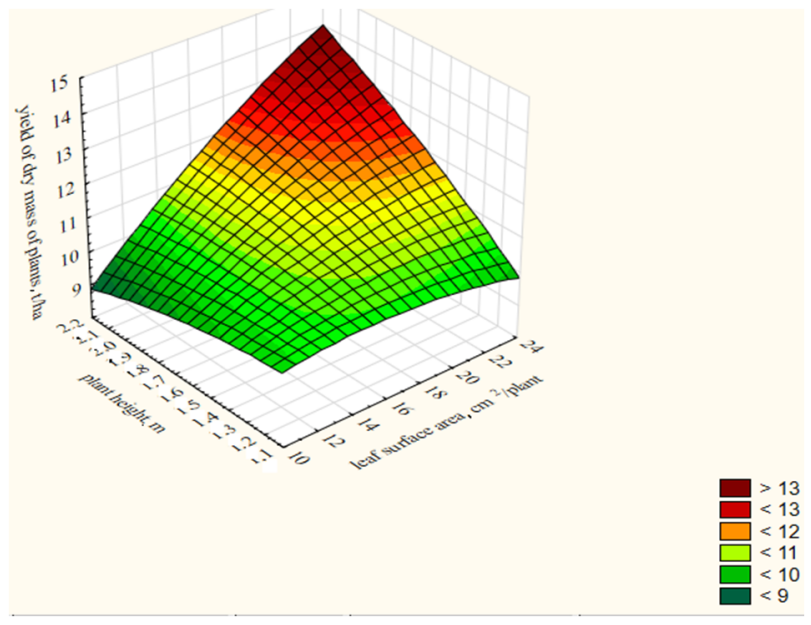

Fig. 4. Dependence of the accumulation of the dry weight of the miscanthus plant on the height of the shoot and the area of the leaf surface.

Thus, the highest productivity of miscanthus is achieved in the trials 7-8, where plants have the largest $\left(24.0 \mathrm{~cm}^{2} /\right.$ plant $)$ leaf area. The coefficients of multiple regression are significant, since the actual value of the tcriterion exceeds the theoretical one by $5 \%$ of the significance level (Table 3).

According to the obtained results, the value of the regression coefficients for the yield of dry mass of plants $\left(F_{\mathrm{f}}=196.32>\mathrm{F}_{0.05}=1.22\right)$ is $-26,356$ with a standard error of 62.9 and the materiality criteria $\operatorname{tf}\left(\mathrm{t}_{0.05}=1.33\right)$ is equal to 7.2. Thus, the value of the regression coefficients for the leaf surface area $\left(F_{f}=66.254>F_{0.05}=1.22\right)$ is -87.4178 
with a standard error of 25.1 and a materiality criterion $\left(\mathrm{t}_{0.05}=1.33\right)$, which equal to 3.5 .

Table 3. Coefficients of multiple regression of the dry weight and the leaf surface area of the miscanthus plant.

\begin{tabular}{|l|l|l|l|}
\hline \multicolumn{5}{|c|}{ The yield of dry mass of the plant $\left(\mathrm{F}_{\mathbf{f}}=196.32>\right.$} \\
\hline $\begin{array}{l}\text { Regression } \\
\text { coefficients }\end{array}$ & $\begin{array}{c}\text { Values of } \\
\text { regression } \\
\text { coefficients }\end{array}$ & $\begin{array}{c}\text { Standar } \\
\mathbf{d} \text { error } \\
\text { Sb }\end{array}$ & $\begin{array}{l}\text { Significanc } \\
\text { e criteria } \mathbf{t}_{\mathbf{f}} \\
\left(\mathbf{t}_{\mathbf{0 . 0 5}}=\mathbf{1 . 3}\right)\end{array}$ \\
\hline c & -26.356 & 62.92730 & 7.204340 \\
\hline bx & 0.7865 & 0.160104 & 10.63481 \\
\hline by & 48.766 & 10.07493 & 5.173311 \\
\hline \multicolumn{5}{|l|}{ Leaf surface area $\left(\mathrm{F}_{\mathrm{f}}=66.254>\mathrm{F}_{0.05}=1.22\right)$} \\
\hline c & -87.4178 & 25.0682 & 3.48704 \\
\hline bx & 4.1611 & 2.2231 & 1.87171 \\
\hline by & 39.3230 & 7.7302 & 5.08694 \\
\hline
\end{tabular}

\section{Discussion}

The dependence of the dry mass of the plant on the shoot height and the leaf surface area based on several biometric parameters. The genetic and physiological mechanisms underlying biomass production of the Miscanthus species awaits further investigation [51]. It was described also highly significant dependence of the number of stomata on the leaf surface and age [52]. The morphometric analysis confirmed higher growth performance of the fertilized trials [53]. Our case study results are consistent with other conclusions that the yield, specific leaf area and leaf area index of Miscanthus stimulated by $\mathrm{N}$ fertilization [54]. The greatest impact on the leaf surface of miscanthus in our field experiment has the height of the plant, the number of stems, which, in turn, depending on the application of fertilizers.

The yield of dry mass of plants depends on the area of the leaf surface and the height of the plant. Miscanthus requires intense sunlight during the growing season to form the optimum leaf area and accumulate sufficient organic matter [55].

The net photosynthetic productivity of miscanthus plants in our research was closely related to the leaf surface area. This dependence characterized by high density $\left(\mathrm{R}^{2}=0.79\right)$.

\section{Conclusions}

It was found that the greatest impact on the leaf surface of miscanthus has the height of the plant and the number of stems, which, in turn, depend on the application of fertilizers. The yield of dry mass of plants depends on the area of the leaf surface and the height of the plant. The largest area of the leaf surface of miscanthus is formed in the trials where fresh sewage sludge was applied in the rate of $20-40 \mathrm{t} / \mathrm{ha}$. The leaf surface area increases from 19.0 up to $24.0 \mathrm{~cm}^{2} /$ plant with increasing rates of SS application. The highest indicators of net photosynthesis productivity were found in the period of intensive growth, which amounted to $7.78 \mathrm{~g} / \mathrm{m}^{2} /$ day and in the maturation period of $7.56 \mathrm{~g} / \mathrm{m}^{2} /$ day in the trial $6(\mathrm{SS}-40 \mathrm{t} / \mathrm{ha}+$ $\mathrm{N}_{10} \mathrm{P}_{14} \mathrm{~K}_{58}$ ). The amount of dry mass of miscanthus plants significantly depends on the height of the shoot and the leaf surface area of the plants. Multiple coefficient of determination $\left(\mathrm{R}^{2}=0.74\right)$ indicates a close correlation between these indicators. The use of compost based on sewage sludge and straw in a ratio of 3:1 at the rate of 30 $\mathrm{t} /$ ha contributes to the dry weight of miscanthus plants at $15 \mathrm{t} / \mathrm{ha}$.

The studies were performed on sod-podzolic soils, which are characterized by relatively low organic matter content, low antidegradation resistance, unsatisfactory agrophysical and agrochemical properties. Thus, the conducted research can serve as a model experiment and be extrapolated to such soils, which are marked by manifestations of degradation of various degrees. In addition, the problem of environmentally safe disposal of sewage sludge is gaining global scale and needs to be addressed. The performed researches partially give the answer to the decision of this problem. One of the ways to solve it is to use sewage sludge as fertilizer for energy crops. Therefore, the studies can be of practical value for use in different regions on other types of soils, which are characterized by varying degrees of degradation processes, which will increase the ecological sustainability of agroecosystems.

\section{References}

1. C. Perpiña Castillo, B. Kavalov, C. Jacobs-Crisioni, C. Baranzelli, F.Batista e Silva, C. Lavalle. Luisa Land Use policy brief. JRC115895 - Ispra, Italy: European Commission, 2019

2. B.Elbersen, I.Startisky, G.Hengeveld, M.J.Schelhaas, H.Naeff, H.Böttcher Biomass futures: Atlas of EU biomass potentials. (2012)

3. J.McCalmont, A.Hastings, N. P. McNamara, G. M.Richter, P.Robson, J. C. Clifton-Brown. Glob. Change Biol. Bioenergy. (2015). doi: 10.1111/gcbb.12294

4. D.Nilsson, H. Rosenqvist, S.Bernesson Profitability of the production of energy grasses on marginal agricultural land in Sweden. Biomass and Bioenergy 83 (2015).

5. V.Scholz, R. Ellerbrock. Biomass and Bioenergy 23:81-92. (2002) DOI: 10.1016/s09619534(02)00036-3.

6. D.Szymańska, J. Chodkowska-Miszczuk. Renew. Sustain. Energy Rev. 15 (2011)

7. I. Zubar, Yu. Onyshchuk The scientific heritage, 48 (2020)

8. G. Drazic, J. Milovanovic, J. Ikanovic, I. Petric, Plant Soil Environ. 63,4 (2017)

9. C.Lesur, M.-H.Jeuffroy, D.Makowski, A.B.Riche, I.Shield, N.Yates, M.Fritz, B.Formowitz, M.Grunert, 
U.Jorgensen, P.E. Laerke Field Crops Research, 149 (2013)

10. R.M.Dierking, D.J.Allen, S.M.Brouder, J.J. Volenec Biomass and Bioenergy, 91 (2016)

11. Milieu Ltd., WRc, RPA: Environmental, economic and social impacts of the use of sewage sludge on land, Final report, Part II: Report on Options and Impacts (2010)

12. S. Alatzas, K. Moustakas, D. Malamis, S. Vakalis. Energies 2019, 12, 1095. doi:10.3390/en12061095

13. D.Huygens, H.G.M. Saveyn Agronomy For Sustainable Development 38, 5 (2018).

14. P.Schröder, N.Beckers, S.Daniels, F.Gnädinger, E.Maestri, N.Marmiroli, M.Mench, R.Millan, M.M.Obermeier, N.Oustriere, T.Persson, C., Pocchenrieder, F.Rineau, B.Rutkowska, T.Schmid, W.Szulc, N.Witters, A.SFbr Science of The Total Environment. 616-617(2018)

15. J. Antonkiewicz, Barbara Kolodziej, E.J. Bieliñska, Anna Poplawska. Soil 21 Science Annual, 70, 1 (2019)

16. M. Szostek, J. Kaniuczak, E.Hajduk, J. StanekTarkowska, T. Jasiński, W. Niemiec, R. Smusz. Archives of Environmental Protection 44, 3 (2018)

17. D.Romanos, N.Nemer, Y. Khairallah et al. Int J Recycl Org Waste Agricult 8, (2019). https://doi.org/10.1007/s40093-019-00310-x

18. M.Bożym, G. Siemiątkowski. Environ Sci Pollut Res 25, (2018). https://doi.org/10.1007/s11356-0183335-x

19. S.Ozcan, A.Tor, M.E. Aydin. Clean Soil Air Water 41( 2013) DOI: 10.1002/clen.201100187

20. C.V.Hung, B.D.Cam, P.T.Mai, B.Q. Dzung. Environ. Geochem. Health 37. 2015

21. M.Zennegg, M.Munoz; P.Schmid, A.C. Gerecke. Environ. Int. 60. 2013

22. X.Zhang, X.Wang, D.Wang. Sustainability 2017, 9 , 2020; doi:10.3390/su9112020

23. M.M.Kharytonov, N.V.Martynova, M.G.Babenko, I.V.Rula. Actual Problems of Natural Sciences: Modern Scientfic Discussions. (2020)

24. B.Kołodziej, M.Stachyra, J.Antonkiewicz, E.Bielińska, J. Wiśniewski Biomass and Bioenergy, 85, (2016).

25. M.Kotrla, Ž.Pauková, M.Prčik Applied ecology and environmental research 17, 6 (2019)

26. B.D. Jankowski, K. J.Załuski, D.M. Sokólski Energy, Elsevier, vol. 206(C). (2020).

27. B.Kołodziej, J.Antonkiewicz, D.Sugier Industrial Crops and Products, 81 (2016).

28. B. Hu, A.M.Jarosch, M.Gauder, S. GraeffHoenninger, J.P.Schnitzler, R.Grote, H.Rennenberg, J.Kreuzwieser, Environmental Pollution 237(2018).

29. E.Lindvall, A.Gustavsson, R.Ramuelsson, T.Magnusson, C.Palmborg. Global Change Biology Bioenergy 7, 3 (2015)
30. M.Kharytonov, V.Pidlisnyuk, T.Stefanovska, M.Babenko, N.Martynova, I.Rula, Environ Sci Pollut Res Int. J. 26, 3(2019)

31. T.Van der Weijde, L.Huxley, S.Hawkins, E. H.Sembiring, K.Farrar, O.Dolstra et al. Glob. Change Biol. Bioenergy. (2016). doi: 10.1111/gcbb.12382.

32. T.Van der Weijde, A.Kiesel, Y.Iqbal, H.Muylle, O.Dolstra, R. G. F.Visser, et al. Glob. Change Biol. Bioenergy (2017). doi: 10.1111/gcbb.12355

33. R.Arundale, F.Dohleman, T.Voigt, S.Long. Bioenergy (2014). Doi:10.1007/s12155-013-93855:1-9

34. L. Strullu, S.Cadoux, M.Preudhomme, M.H.Jeuffroy, N.Beaudoin. Field Crops Research 121 (2011). DOI: 10.1016/j.fcr.2011.01.005.

35. J.Clifton-Brown, K.U.Schwarz, A. Hastings Biology and Environment: Proceedings of the Royal Irish Academy 115, 1(2015)

36. N.Roncucci, N.Nassi O Di Nasso, C.Tozzini, E.Bonari, G. Ragaglini, Gcb Bioenergy 7, 5(2015)

37. A.Faber, R.Borek, M.Borzęcka -Walker. Acta Agrophys. 4, 2007

38. T. Krička, A. Matin, N. Bilandžija, V. Jurišić, A. Antonović, N. Voća, M. Grubor. Int. Agrophys., 31. (2017)

39. N.Wanat, A.Austruy, E.Joussein, M.Soubrand, A.Hitmi, C.Gauuthier-Moussard, J.-F.Lenain, P.Veranay, J.C.Munch, M.Pichon. Journal of Geochemical Explorations 126-127 (2013)

40. M.H.Stietiya, J.J.Wang J. Environ. Qual. 40 (2011)

41. E.Anderson, R.Arundale, M.Maughan, A.Oladeinde, A.Wycislo, T. Voigt, Biofuels, 2:1, (2011).

42. N. Amougou, I. Bertrand, S.Cadoux,S. Recous GCB Bioenergy 4,6(2012)

43. M.Matyka, J. Kus, Polish Journal of Environmental Studies, 25, 1 (2016).

44. F. J.Montero, J. A. de Juan, A.Cuesta, A.Brasa, Hort Science. 35, 4 (2000)

45. L.Williams, T. E. Martinson, Sci Hortic. 98. (2003).

46. C.V. Beale, D.A. Bint, S.P. Long Journal of Experimental Botany, 47, 295, (1996)

47. S.Cadoux, A.B.Riche, N.E.Yates, J.-M. Machet Biomass and Bioenergy, 38(2012)

48. E.A. Heaton, F.G. Dohleman, A.F. Miguez, J.A. Juvik, V. Lozovaya, J. Widholm, O.A. Zabotina, G.F.McIsaac, M.B. David, T.B. Voigt, N.N. Boersma, S.P. Long Advances in Botanical Research 56 (2010)

49. H.W. Zub, M. Brancourt-Hulmel. Agron. Sustain. Dev. 30 (2010)

50. N.P. R. Anten, T. Hirose Journal of Ecology. 87, 4 (1999)

51. Juan Yan et al., GCB Bioenergy 4, (2012)

52. Z.Jureková, M.Kotrla, Ž.Pauková, Acta regionalia et environmentalica 2, (2013)

53. M.Kotrla, Ž.Pauková, M.Prčik. Applied ecology and environmental research. 17,6 (2019) 
54. D. Wang, M.W.Maughan, J. Sun, X. Feng, F. Miguez, D.K. Lee, M. C. Dietze GCB -Bioenergy 4, 6 ( 2012)

55. L.Pravdyva, M.Grabovskyi, L. Kachan, V.Khakhula, Y.Fedoruk, S. Hornovska. Plant Archives, 20,2, (2020) 